\title{
LAFIAL: Pandemi COVID-19 Sebagai Momentum Kemandirian Industri Farmasi Menuju Ketahanan Kesehatan Nasional
}

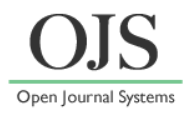

\author{
Dandung Ruskar ${ }^{1, *}$, Septianita Hastuti ${ }^{2}$, Heri Wahyudi ${ }^{3}$, I Dewa Ketut Kerta Widana ${ }^{1}$, \\ Rio Khoirudin Apriyadi ${ }^{1}$ \\ ${ }^{1}$ Prodi Manajemen Bencana, Fakultas Keamanan Nasional, Universitas Pertahanan, Indonesia \\ ${ }^{2}$ Fakultas Farmasi dan Sains, Universitas Muhammadiyah Prof. Dr. Hamka, Indonesia \\ ${ }^{3}$ Lembaga Farmasi TNI Angkatan Laut Drs. Mochamad Kamal, Indonesia \\ *Email: dandungruskar100@gmail.com
}

DOI: https://doi.org/10.33369/pendipa.5.3.300-308

\begin{abstract}
[LAFIAL: COVID-19 Pandemic As The Pharmaceutical Industry's Independence Momentum Towards National Health Resilience] Ninety percent of the distribution of medicinal raw materials and medical devices of the domestic pharmaceutical industry is sourced from imports from other countries. One of the exporter countries is China which still feels it has sovereignty over part of the North Natuna Sea (LNU) in the South China Sea conflict (LCS). In the conflict, Indonesia vehemently denies any unilateral claims from China. This has the potential to stop import access to Indonesia which ultimately has an impact on the development of the domestic pharmaceutical industry. In Presidential Instruction No. 6 of 2016, the government wants the realization of the resilience of the domestic pharmaceutical industry. Industrial resilience in the pharmaceutical sector has multi-benefits including accelerating national economic growth, meeting the scarcity of pharmaceutical products and medical devices as a result of COVID-19, and at the same time reducing import dependence on medicinal raw materials and medical devices. Navy Pharmaceutical Institute (LAFIAL) as the military pharmaceutical industry has a strategic capacity and role against both military and nonmilitary threats that can harm the health of the people of Indonesia. The involvement of LAFIAL is expected to further encourage and strengthen the independence of the pharmaceutical industry. This article is qualitative research through a descriptive approach with an analysis of studies from several references to describe the current pharmaceutical industry profile and the COVID-19 pandemic impact affecting the pharmaceutical industry independence, coupled with interviews from several sources. The interview results provide an overview of how the LAFIAL benefits as a military pharmaceutical industry to support health defense, especially during the COVID-19 pandemic.
\end{abstract}

Keywords: COVID-19 pandemic; Health Defense; Independence of the Pharmaceutical Industry; Navy Pharmaceutical Institute.

\begin{abstract}
ABSTRAK
Sembilan puluh persen distribusi bahan baku obat dan alat kesehatan industri farmasi dalam negeri bersumber dari impor dari negara lain. Salah satu negara eksportir adalah negara Cina yang mana masih merasa memiliki kedaulatan atas sebagian dari Laut Natuna Utara (LNU) dalam konflik Laut Cina Selatan (LCS). Dalam konflik tersebut Indonesia secara tegas membantah klaim sepihak dari Cina. Hal ini berpotensi besar terjadinya penghentian akses impor ke Indonesia yang pada akhirnya berdampak terhadap perkembangan industri farmasi dalam negeri. Dalam Instruksi Presiden (Inpres) Nomor 6 Tahun 2016, pemerintah menghendaki adanya perwujudan ketahanan industri farmasi dalam negeri. Ketahanan industri di bidang farmasi memiliki multi-benefit diantaranya dapat mempercepat pertumbuhan ekonomi nasional, memenuhi kelangkaan produk farmasi dan alat kesehatan sebagai dampak dari COVID-19 dan sekaligus mengurangi ketergantungan impor atas bahan baku obat dan alat kesehatan. Lembaga Farmasi
\end{abstract}


TNI AL (LAFIAL) sebagai industri farmasi TNI memiliki kapasitas dan peranan yang strategis untuk menangkal ancaman baik militer dan nirmiliter yang dapat membahayakan kesehatan masyarakat Indonesia. Dengan adanya keterlibatan LAFIAL diharapkan dapat lebih mendorong dan menguatkan kemandirian industri farmasi. Artikel ini merupakan penelitian kualitatif melalui pendekatan deskriptif dengan analisis kajian dari beberapa referensi untuk menggambarkan profil industri farmasi saat ini dan dampak pandemi COVID-19 mempengaruhi kemandirian industri farmasi, ditambah dengan wawancara beberapa narasumber. Hasil wawancara memberikan gambaran bagaimana manfaat LAFIAL sebagai industri farmasi militer guna mendukung pertahanan kesehatan terutama dalam masa pandemi COVID19.

Kata kunci: Pandemi COVID-19; Pertahanan Kesehatan; Kemandirian Industri Farmasi; Lembaga Farmasi TNI-AL.

\section{PENDAHULUAN}

Menurut Peraturan Menteri Pertahanan Republik Indonesia Nomor 20 Tahun 2014 tentang Sistem Kesehatan Pertahanan Nasional disebutkan bahwa perlu adanya pengembangan kapasitas sumber daya kesehatan nasional dalam rangka mendukung upaya bela negara. Kemampuan ini secara fundamental mencerminkan efektivitas tempur dan pencegahan sistem kesehatan pertahanan nasional dalam menghadapi berbagai tantangan kesehatan yang dinamis, yang dapat mengancam integritas dan stabilitas negara. Kapabilitas tersebut juga menjadi salah satu fondasi bagi pembentukan ketahanan nasional terhadap bencana, dan kekuatan kesehatan nasional merupakan salah satu kekuatan penunjang pertahanan negara. Kekuatan nasional bidang kesehatan memerlukan pembinaan dan persiapan yang berkelanjutan untuk mendukung kegiatan pertahanan negara dan melindungi masyarakat dari berbagai ancaman (Junus, 2016).

Sehubungan dengan itu, upaya pencegahan pandemi COVID-19 di Indonesia masih belum memberikan hasil perkembangan yang positif, semakin hari jumlah pasien semakin meningkat. Berdasarkan laporan dari Worldometer per 02 Desember 2020 menyebutkan bahwa Indonesia menempati ranking 5 (lima) peringkat kasus COVID-19-19 di Asi (Alam, 2020). Kemudian data terbaru tentang perkembangan kasus di Indonesia per kamis tanggal 28 Januari 2021 menyebutkan kasus positif bertambah 13.695 kasus dengan pasien sembuh bertambah 10.792 dan pasien meninggal dunia bertambah 476 orang (Moerti, 2021). Peningkatan jumlah kasus ini tentunya tidak lepas dari upaya penanganan Pemerintah dan partisipasi masyarakat yang masih belum maksimal mulai dari pembatasan sosial, gerakan 3M dan gerakan 3T. Untuk lebih jelasnya melihat perkembangan kasus COVID19 di Indonesai sepanjang tahun 2020 dan awal bulan 2021 ditunjukkan melalui grafik di Gambar 1.

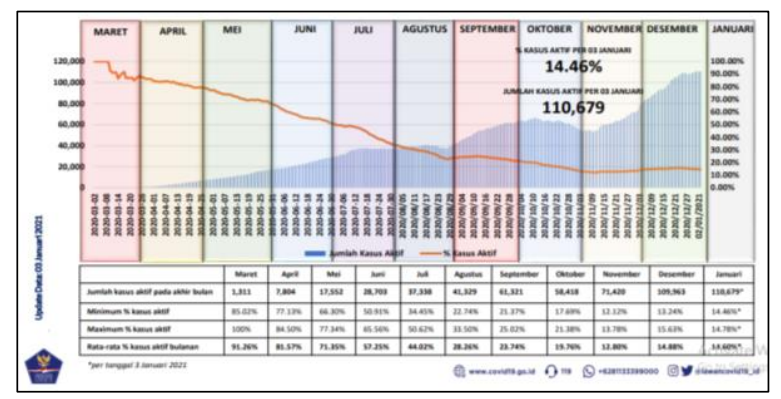

Gambar 1. Jumlah dan Persentase Kasus Aktif di Tingkat Nasional (Satgas Penanganan COVID-19, 2020)

Dampak COVID-19 di Indonesia diprediksikan dalam waktu sekitar dua tahun akan berakhir. Perkiraan ini berdasarkan proses vaksinasi yang membutuhkan uji klinis dan memakan waktu lama. Beberapa vaksin untuk melawan COVID-19 telah memberikan hasil uji klinis yang memenuhi persyaratan, dan diharapkan melalui vaksin ini akan memicu terbentuknya kekebalan kelompok (herd immunity) untuk memerangi COVID-19. Citi Research menunjukkan bahwa kekebalan kelompok mungkin tidak terbentuk hingga akhir 2021 (Ngurah Diksa, 2021). Senada dengan itu, World Health Organization (WHO) mengatakan meskipun vaksin sudah didistribusikan ke beberapa negara, herd immunity belum tentu akan terbentuk di tahun 2021. Hal tersebut disebabkan karena proses distribusi virus juga membutuhkan waktu untuk melakukan proses 
produksi dan pengujian, dan dosis yang digunakan harus cukup untuk dapat melawan virus corona (Ariawan \& Jusril, 2020). Secara tidak langsung hal tersebut menunjukkan bahwa vaksinasi adalah satu-satunya jalan pilihan yang harus diambil untuk bisa lepas dari pandemi ini. Akan tetapi setelah melihat dinamika pandemi tersebut sejauh ini, WHO sendiri mengungkapkan bahwa terdapat 3 (tiga) varian baru dari COVID-19. Varian tersebut adalah: 1) Varian B-117 berasal dari Inggris yang disinyalir lebih mudah dalam penularan; 2) Varian B-1351 dari Afrika Selatan dan 3) Varian B-1128 dari Brazil. Kedua jenis varian terakhir dilaporkan tidak terpengaruh dengan penetralan oleh vaksin (Mahfut, 2020).

Melihat kejadian tersebut di atas, sebaiknya pemerintah tidak menggantungkan bahwa vaksinasi merupakan satu-satunya jalan terbaik untuk mengatasi pandemi ini. Harus ada pemikiran jalan lain untuk dijadikan sebagai langkah atau strategi lain yang akhirnya diterapkan secara bersamaan dengan vaksinasi. Apabila pemerintah hanya mengandalkan terhadap vaksinasi saja, maka dampaknya kedepan adalah pandemi COVID-19 tidak akan pernah berakhir di Indonesia. Pemerintah akan dianggap gagal dalam melaksanakan amanah dari Pembukaan Undang-Undang Dasar tahun 1945 alinea ke-empat yaitu melindungi segenap warga negara dari segala macam ancaman. Untuk itu ketahanan kesehatan nasional menjadi salah satu faktor penting untuk diwujudkan agar selalu siap senantiasa setiap saat jika diperlukan sebagai penangkal berbagai ancaman, hambatan, gangguan dan tantangan dengan memberikan dukungan maksimal terhadap pelaksanaan operasi pertahanan negara. Sehingga pembinaan sejak dini terhadap kemandirian dan kekuatan kesehatan nasional harus menjadi prioritas agar tercapai ketahanan nasionaI tingkat tertentu (Lardo, 2020).

Tiga faktor utama yang menyebabkan usaha dan upaya penanganan COVID-19 di Indonesia masih belum maksimal dalam kurun waktu sepanjang tahun 2020 yaitu : 1) Respon yang lambat dari pemerintah; 2) Tidak efektif dalam melakukan strategi distribusi sumber daya kesehatan dan 3) Terbatasnya partisipasi masyarakat (Agustino, 2020). Terkait dengan respon yang lambat dan strategi distribusi sumber daya kesehatan yang tidak efektif, tercapainya kualitas yang maksimal atas pelayanan kesehatan terhadap pasien COVID-19 juga masih terkendala dari beberapa sisi. Salah satu kendala tersebut adalah keterbatasan jumlah obat yang digunakan dalam menangani pasien positif. Sejauh ini, siklus pengadaan obat untuk pasien positif masih mengandalkan impor dari negara lain yang tentunya akan memperlambat proses penanganan pasien sehingga akan menurunkan mutu pelayanan kesehatan yang ada saat ini (Raharni, Supardi, \& Sari, 2018). Mengingat pandemi ini berdampak secara global di seluruh dunia, akan terjadi pemikiran bahwa negara importir tersebut akan memenuhi kebutuhan negaranya dahulu sebelum memenuhi kebutuhan negara lain. Sehingga harus ada strategi-strategi lain yang harus menjadi dasar pertimbangan bagi pemerintah untuk dengan segera mengatasi pandemi ini mengingat bahwa pandemi ini berakhir dalam waktu yang belum bisa dipastkan dan dampak yang ditimbulkan begitu masif. Untuk itulah pemerintah harus berupaya untuk mengurangi permintaan impor dengan jalan memajukan dan menguatkan kemandirian industri farmasi dalam negeri. Hal ini sesuai dengan Inpres 6/2016 yaitu dalam rangka membentuk industri farmasi dan industri alat kesehatan nasional yang mandiri dan memiliki daya saing.

Adanya keterlibatan dan peran serta Tentara Nasional Indonesia (TNI) dalam penangangan dan pengendalian bencana sudah terbukti di beberapa daerah. Dimana kesiapan, ketangguhan dan ketanggapan TNI sebagai garda terdepan menjadi andalan sebagai perwujudan kehadiran pemerintah dalam memberikan respon cepat terhadap bencana. Dalam rangka mewujudkan kapasitas ketahanan kesehatan nasional, sehingga siap sewaktu-waktu dalam melawan segala bentuk ancama dan dalam rangka untuk mendukung penyelenggaraan operasi pertahanan negara, maka tentunya Lembaga Farmasi TNI AL (LAFIAL) memiliki peranan yang strategis dalam memberikan respon yang cepat di bidang kesehatan. Dengan letaknya yang berada di ibukota negara yang memiliki angka pasien COVID-19 tertinggi skala nasional, ditambah dengan pengabdian tanpa batas sebagai aparatur negara sekaligus sebagai pelayanan kesehatan diharapkan LAFIAL dapat turut serta 
berpartisipsi sebagai industi farmasi yang handal dan profesional untuk senantiasa mendukung upaya pemerintah dalam menangani pandemi ini. Melalui latar belakang di atas, maka pada artikel kali ini kami akan menyampaikan peran penting LAFIAL sebagai industri farmasi dalam negeri dalam memenuhi kebutuhan medis masyarakat, meningkatkan kualitas pelayanan kesehatan, dan menciptakan kondisi kesehatan yang setinggitingginya.

\section{METODE PENELITIAN}

Penelitian ini menggunakan pendekatan deskriptif kualitatif dengan kajian beberapa referensi dan wawancara narasumber terpercaya. Analisa kajian pustaka ditujukan untuk memberikan gambaran profil industri farmasi saat ini dan dampak pandemi COVID-19 terhadap kemandirian industri farmasi dan hasil wawancara dengan tujuan memberikan gambaran dan manfaat LAFIAL sebagai industri farmasi militer guna mendukung pertahanan kesehatan terutama dalam masa pandemi COVID-19.

\section{HASIL DAN PEMBAHASAN}

\section{Profil Industri Farmasi Dalam Negeri Indonesia}

Perbedaan utama antara industri farmasi dan industri lainnya adalah bahwa industri farmasi merupakan industri padat modal, beroperasi dengan teknologi terkini (high-tech), pemilihan produk melalui penelitian (R\&D intensif), regulasi dan kebijakan yang ketat (pengawasan ketat), dan pasar Itu terfragmentasi (pasar desentralisasi). Industri farmasi dalam negeri mampu memenuhi $75 \%$ kebutuhan pasar obat nasional (Seto, Nita, \& Triana, 2015). Menurut laporan, jumlah industri farmasi dalam negeri adalah 206 (dua ratus enam) industri, dimana 178 (seratus tujuh puluh delapan) dikuasai oleh perusahaan swasta negara, 24 (dua puluh empat) perusahaan multinasional, dan hanya 4 (empat) diantaranya adalah Badan Usaha Milik Negara (BUMN). Industri farmasi dalam negeri merupakan salah satu industri yang mampu bertahan sejak dulu dan saat ini memiliki kemampuan untuk memenuhi $75 \%$ kebutuhan obat dalam negeri. Akan tetapi masih ada beberapa kendali yang dialami oleh industri farmasi dalam negeri terkait dengan hasil produksinya dimana hampir $90 \%$ BBO bersimber dari impor (Mawarti, 2017).
Jumlah industri farmasi yang memproduksi BBO di tahun 2016 sebesar 8 (delapan) industri dan diharapkan bisa berkembang menjadi 14 (empat belas) industri, dan industri obat tradisional diharapkan bertambah dari 88 (delapan puluh delapan) industri menjadi 120 (seratus dua puluh) industri termasuk juga industri farmasi untuk ekstrak bahan alami diharapkan berkembang dari 8 (delapan) industri menjadi 17 (tujuh belas) industri dan industri alkes dalam negeri diharapkan mengalami penambahan dari 215 (dua ratus lima belas) industri menjadi 313 (tiga ratus tiga belas) industri. Saat ini, fokus pengembangan bahan baku sediaan farmasi secara bertahap dibagi menjadi empat fokus utama yakni BBO yang berasal dari alam, bahan baku obat dari sintesis reaksi bahan kimia (API), Biopharmaceutical, dan terakhir adalah vaksin (Nugroho, 2017) dan terdapat 3 (tiga) BBO yang diproduksi masih dalam tahapan lebih lanjut untuk memenuhi persyaratan sertifikasi "Good Manufacturing Practice" (GMP) (Zuhriyah, 2019).

Seperti yang dikemukakan sebelumnya, hampir $90 \%$ kebutuhan BBO industri farmasi Indonesia masih mengandalkan bahan baku farmasi yang diimpor dari negara lain (yakni China dan India). Berpotensi memberikan dampak negatif pada daya saing obat-obatan negara, karena melemahnya daya tawar importir, obat akan semakin tergerus. Hambatan lain yang muncul adalah kebutuhan pereaksi atau reagensia kimia atau biologi untuk dapat melakukan proses produksi dan pemurnian yang banyak di antaranya masih mengandalkan impor dari negara lain (Agustina \& Herman, 2016). Disamping itu, substitusi atas salah satu bahan baku obat untuk produksi obat akan memerlukan proses yang rumit dan memakan waktu lama terkait dengan proses dalam pendaftaran registrasi ulang ke Badan Pengawas Obat dan Makanan (BPOM). Suatu industri farmasi pasti memiliki lebih dari satu pemasok bahan baku yang disertakan secara bersamaan pada saat pendaftaran. Apabila jalur masuk produk impor ditutup, pastinya akan mengancam produksi obat. Sehingga dengan adanya campur tangan pemerintah diharapkan kemandirian industri farmasi dalam negeri meningkat sehingga kebutuhan obat dan BBO, alat kesehatan, alat pelindung diri (APD), masker dan ventilator 
dapat dipenuhi untuk mempercepat upaya penanganan COVID-19 di Indonesia (Rizni, 2016).

\section{Kebangkitan Indusrtri Farmasi Dalam Negeri Ditengah Pandemi}

Percepatan Pembangunan Industri Farmasi dan Alat Kesehatan diatur dalam Inpres 6/2016 dengan tujuan menciptakan industri farmasi dan alat kesehatan nasional yang mandiri, sehingga bermanfaat bagi masyarakat Indonesia dengan kemudahan akses memperoleh obat, harga terjangkau dan dalam jumlah yang memadai, serta berkelanjutan. Hal ini akan menjadi zaman keemasan bagi industri farmasi dalam negeri agar dapat meningkatkan perannya dalam rangka peningkatan taraf hidup masyarakat Indonesia (Kemenperin, 2020). Selain itu, wabah COVID19 justru berperan terhadap perkembangan industri farmasi dalam negeri. Adanya impor BBO akan mempengaruhi proses ekonomi dan bisnis perusahaan farmasi dalam negeri. Dalam keadaan ini industri farmasi dalam negeri pada akhirnya dipaksa untuk mendiversifikasi rantai pasokan bahan bakunya ke negara lain (Indramadhini \& Sitompul, 2015). Menurut Oxford Business Group (OBG) menilai bahwa kapasitas produksi farmasi dalam negeri perlu ditingkatkan untuk memenuhi kebutuhan obat yang mendesak agar dapat melindungi negara (Admin KNIC, 2020).

Hal senada disampaikan oleh Indonesia International Institute for Life Science (i3L) bahwa akan terdapat peningkatan positif bagi industri farmasi selama COVID-19 berlangsung. Intervensi dan dukungan pemerintah yaitu meringankan regulasi dan deregulasi dengan melonggarkan tarif pajak dan subsidi kepada peserta komersial, dapat mendorong peningkatan industri, termasuk kesulitan yang dihadapi industri farmasi pada saat pandemi. Dan saat ini terbuka pintu lebar untuk impor BBO dari negara lain. Perusahaan multinasional Moody's juga memprediksi dampak COVID-19 akan mempercepat laju peningkatan industri farmasi skala global. Badan Pengembangan Sumber Daya Manusia Industri (BPSDMI) menyebutkan bahwa pada tahun 2020, industri farmasi dan kimia, industri jamu / obat asli dalam negeri, akan tumbuh positif. Faisal Basri, Senior Economist Institute of Economic and Financial
Development (Indef) memperkirakan industri farmasi termasuk industri obat tradisional, industri kimia, dan produk berbahan kimia akan mengalami pemulihan pada tahun 2021 dan akan meningkat (Herdady \& Muchtaridi, 2020).

Ketergantungan vaksin juga harus di cermati mengingat vaksin dinilai masih tidak bisa mengejar laju kecepatan pandemi. Takutnya sebelum program vaksinasi nasional selesai, banyak orang akan tertular dan terkena gangguan kesehatan yang akan menyebabkan semakin banyaknya kematian. Oleh karena itu, dari segi kesehatan dan sosial ekonomi, pemulihan membutuhkan waktu yang lama. Tentu saja, situasi ini harus dapat diramalkan, dan pemerintah harus terus fokus pada penerapan protokol kesehatan termasuk 3T atau pengujian, pelacakan dan pengobatan (pengujian, pelacakan dan pengobatan) dan tidak semata-mata menjadikan vaksin sebagai satu-satunya jalan keluar terakhir (Sari \& Sriwidodo, 2020).

Dalam seminar online yang diselenggarakan oleh Directorate Innovation and Science Techno Park Universitas Indonesia (DISTP UI) tentang pengembangan Vaksin Merah Puith, diharapkan dapat meningkatkan kepercayaan masyarakat atas upaya pemerintah dalam merespon pandemi. Pengembangan vaksin dalam negeri diharapkan akan meningkatkan perekonomian sehingga diharapkan dapat mengembalikan fungsi dan ekonomi nasional di penghujung tahun 2021. Percepatan pengembangan vaksin pastinya memerlukan bentuk kerja sama antara Pemerintah, industri farmasi dalam negeri, dan pihak akademisi yang kemudian disebut dengan bentuk kerja sama Triple Helix. Lebih jauh diharapkan nantinya Indonesia justru dapat mengekspor vaksin buatan dalam negeri ke negara lain untuk mewujudkan kemandirian vaksin di Indonesia dan meningkatkan perekonomian nasional (Lee \& Kim, 2016) (Redaksi WE, 2021).

Selain vaksin, kemudahan akses serta ketersediaan obat yang aman, bermutu dan terjangkau juga sangat dibutuhkan oleh masyarakat Indonesia, terutama di masa pandemi ini (Kaban et al., 2018). Melalui Kementerian Perindustrian (Kemenperin), pemerintah terus berupaya kemandirian industri farmasi dalam negeri. Kemenperin juga bertekad untuk memperjuangkan kemandirian industri farmasi 
dan alat kesehatan dalam negeri dan berupaya menekan kenaikan jumlah impor BBO sintetik (obat kimia) yaitu dengan menggunakan metode berbasis pemrosesan untuk menghitung Nilai Tingkat Kandungan Dalam Negeri (TKDN) obat dan tidak menggunakan metode biaya. Kebijakan ini tertuang dalam Peraturan Menteri Perindustrian Nomor 16 Tahun 2020, yang mengatur tentang ketentuan dan tata cara penghitungan Nilai Tingkat Kandungan Dalam Negeri (TKDN) obat. Selain itu, Kementerian Perindustrian mengambil langkah strategis untuk membangun dan mengembangkan industri farmasi penghasil BBO dalam negeri, serta mengembangkan industri farmasi yang menggunakan bahan tumbuhan herbal untuk menghasilkan Obat Modern Asli Indonesia (OMAI) melalui pemanfaatan sumber alam dalam negeri (Usman, 2018).

Dilihat dari segi pertahanan dan keamanan negara, dengan adanya kemandirian industri di bidang farmasi sangatlah diperlukan bila dikaitkan dengan panasnya konflik ideologi negara yang berada di Laut Cina Selatan (LCS). Dimana dalam konflik LCS yang berkepanjangan tersebut menceritakan klaim sepihak Cina atas sebagian wilayah di Laut Natuna Utara dengan teori Nine Dash Line. Bila sebelumnya disebutkan bahwa impor bahan baku obat Indonesia sebesar 90 persen dengan Cina sebagai salah satu negara importir, maka hal ini akan berpotensi besar untuk melemahkan kekuatan bangsa dari dalam. Dalam artian bila kita tidak sependapat atau menolak klaim Cina atas sebagian wilayahnya di Laut Natuna Utara, maka dicemaskan akan terjadi embargo atas bahan baku obat. Berpikir lebih jauh apabila tidak terjadi embargo atas bahan baku obat, kemungkinan lain adalah timbulnya potensi penyalahgunaan atas bahan baku obat yang yang akan diterima oleh Indonesia. Tentunya hal ini harus dihindari mengingat konflik LCS masih memanas.

\section{LAFIAL Mewujudkan Kemandirian Industri Farmasi}

LAFIAL berdiri pada 22 Agustus 1963 dan berlokasi di Jalan Bendungan Jati Luhur No.1. Gedung 1, Bendungan Hilir, Jakarta Pusat dengan peran dukungan atas obat-obatan dalam Operasi Trikora, Operasi Dwikora dan Operasi
Timor-Timur (yang akhirnya memisahkan diri dari Indonesia dan berubah nama menjadi Timor Leste) melalui Keputusan Dirjen POM No. 05411/A/SK/XII/1989. Dengan dasar tersebut, menjadikan LAFIAL sebagai insdustri farmasi yang memiliki unsur dukungan tempur berupa dukungan logistik kesehatan. Perkembangan LAFIAL dari masa ke masa semakin meningkat sesuai tuntutan dan perkembangan zaman, termasuk juga dalam upaya meningkatkan kapasitas tenaga farmasi TNI-AL melalui peran serta dalam program pelatihan dan pendidikan. Nama LAFIAL semakin dikenal sebagai pusat kegiatan produksi dan laboratorium TNI-AL hingga membentuk hubungan kerja sama dengan lembaga industri farmasi di luar lingkungan TNIAL melalui sejumlah penelitian-penelitian berskala nasional yang pada akhirnya menjadikan LAFIAL sebagai Centre of Community dari seluruh Apoteker TNI-AL di Indonesia. Guna lebih meningkatkan peran dan fungsi dari para Apoteker TNI-AL maka dibentuklan Tim Farmasi Kelautan yang memiliki tugas pokok melakukan sejumlah penelitian yang berkaitan dengan sediaan produk matra kelautan dalam rangka eksplorasi berbagai kandungan dan kegunaan bahan alam yang bersumber dari laut dan penelitian-penelitan lain yang dapat memiliki daya dukung dan daya guna terhadap operasi militer serta peningkatan taraf hidup kesehatan bagi anggota militer TNI-AL beserta keluarganya.

Perkembangan terbaru LAFIAL Drs. Mochamad Kamal terkini adalah penerbitan izin industri farmasi kepada LAFIAL oleh Menteri Kesehatan melalui Kepmenkes Republik Indonesia Nomor: FP.01.03/IV/0078/2017 tentang Izin Industri Farmasi LAFIAL dan memiliki 4 (empat) sertifikat CPOB terkini untuk bentuk sediaan tablet, kapsul keras, cairan oral dan sediaan semisolid termasuk juga untuk sediaan antibiotik non betalaktam. Dan hingga sekarang LAFIAL sedang melakukan proses registrasi obat untuk 30 (produk) rencana produksi dan 5 (lima) diantaranya sudah mendapatkan perijinan registrasi produk dari BPOM.

Pada acara pembukaan seminar selama 2 (dua) hari yaitu dari tanggal 11 sampai dengan tanggal 12 April 2019 yang diselenggarakan oleh TNI-AL, Kepala Dinas Kesehatan Angkatan 
Laut (Kadiskesal) menyampaikan bahwa LAFIAL dengan Universitas Gajah Mada (UGM) telah mendapatkan kepercayaan sebagai bentuk mitra industri farmasi melalui penelitian dan produksi bersama sediaan cair vitamin D nanoemulsion (OST-D) yang bermanfaat bagi masyarakat (Arman, 2019). Peran LAFIAL Drs. Mochamad Kamal dalam menangani COVID-19 dicapai dengan memproduksi vitamin dan hand sanitizer untuk memenuhi kebutuhan prajurit yang kekurangan vitamin dan produk hand sanitizer di pasaran saat COVID-19 merebak. Kemudian pada Maret 2020 LAFIAL juga memproduksi vitamin dan hand sanitizer yang telah didistribusikan kepada prajurit di berbagai departemen di lingkungan Mabes TNI. (Puskes TNI, 2020).

Sebagai salah satu institusi militer, LAFIAL juga memiliki peranan yang strategis untuk terus tetap menjaga kualitas dan mutu produk yang akan dibuat secara berkesinambungan dan konsisten. LAFIAL juga memiliki komitmen untuk selalu berkontribusi memberikan pelayanan kesehatan untuk menciptakan derajat kesehatan manusia Indonesia setinggi-tingginya dalam bentuk produksi obat. Terlebih bila terjadi darurat militer atau peperangan yang sewaktuwaktu dapat timbul, apalagi dengan situasi konflik perbatasan maritim yang saat ini adalah konflik LCS. Kehadiran LAFIAL sebagai bentuk ketahanan farmasi militer akan selalu kokoh berdiri dan tetap memberikan pelayanan kesehatan disaat industri farmasi lain mengalami keterpurukan. Selain itu, jika tidak ada lagi keluhan tentang kelangkaan obat, obat palsu dan obat mahal, maka pelayanan kesehatan dapat diberikan semaksimal mungkin. Melalui Instruksi Presiden (Inpres) kepada pabrik farmasi militer (AL, $\mathrm{AD}$, dan $\mathrm{AU}$ ) dan pabrik farmasi milik Polri, diperlukan adanya peningkatan kapasitas produksi. Selain untuk memenuhi kebutuhan pelayanan kesehatan internal TNI dan Polri, sisanya dapat digunakan untuk kepentingan seluruh rakyat (Redaksi JSS, 2016).

\section{KESIMPULAN}

Seperti diketahui bahwa baik sebelum dan saat adanya pandemi COVID-19, industri farmasi menggantungkan 90 persen kebutuhannya melalui impor bahan baku. Tentunya hal ini akan sangat meresahkan kesehatan nasional terlebih di masa pandemi ini dimana dampaknya juga ke seluruh dunia. Sebagian besar bahan baku merupakan hasil impor dari negara China dan India yang juga merupakan negara dengan angka pandemi COVID-19 terbesar dan bahkan termasuk kedalam 5 (lima) besar. Pemerintah harus memikirkan strategi lain untuk mengatasi hal ini dan salah satunya adalah meningkatkan dan mengembangkan sektor industri farmasi dalam rangka ketahanan negara. Ketahanan industri farmasi ini ditujukan untuk meningkatkan derajat kesehatan warga negara Indonesia melalui pemenuhan kelangkaan kebutuhan medis. Ketahanan di bidang industri farmasi sekaligus merupakan strategi pendamping untuk mewujudkan kesehatan masyarakat Indonesia secara merata dan bermutu. Terlebih di tahun 2021 ini juga mulai bermunculan pemberitaan tentang adanya varian baru dari COVID-19 yang dikabarkan tidak terpengaruh oleh vaksin.

Dalam hal ini, pengembangan industri farmasi sangat diperlukan melalui pemenuhan sumber daya dan teknologi yang kompeten. Manfaat lain yang juga bisa didapatkan adalah percepatan pemulihan ekonomi dikarenakan industri farmasi bisa menjadi sarana komoditi dan produknya juga bisa dijual di pasar. Melalui pengembangan produksi vaksin, penambahan industri BBO dan industri alat kesehatan, industri bahan kimia dan industri obat tradisional secara Triple Helix diharapkan dapat mengurangi ketergantungan atas impor sekaligus meningkatkan kesehatan dan ekonomi masyarakat. LAFIAL sebagai industri farmasi militer juga telah berperan serta selama ini dalam mewujudkan ketahanan industri melalui bentuk dukungan kesehatan terhadap prajurit TNI AL dan keluarganya, memperbaharui perijinan produksi obat dan melakukan registrasi produk serta kerja sama dengan pihak luar untuk membantu mewujudkan ketahanan kesehatan masyarakat di Indonesia. Peran ini juga dapat dimanfaatkan untuk mendukung kebijakan pemerintah dalam menangani pandemi, mempercepat kebangkitan ekonomi dan mewujudkan pertahanan negara yang tangguh melalui pertahanan kesehatan.

\section{DAFTAR PUSTAKA}

Admin KNIC. (2020). Perkembangan Industri 
Farmasi di Indonesia Dari Zaman Penjajahan Hingga di Tengah Pandemi. Retrieved from https://www.knic.co.id/id/bagaimanaperkembangan-industri-farmasi-diindonesia

Agustina, S., \& Herman, S. (2016). Potensi mikroalga sebagai bahan kimia ADI. Bbkk. Kemenperin. Go. Id, 3(1).

Agustino, L. (2020). Analisis Kebijakan Penanganan Wabah Covid-19: Pengalaman Indonesia. Jurnal Borneo Administrator, 16(2), 253-270. Retrieved from https://doi.org/10.24258/jba.v16i2.685

Alam, S. O. (2020). Masuk 5 Besar, Kasus COVID-19 Indonesia Peringkat Berapa di Asia? Retrieved from https://health.detik.com/beritadetikhealth/d-5277872/masuk-5-besarkasus-covid-19-indonesia-peringkatberapa-di-asia

Ariawan, I., \& Jusril, H. (2020). COVID-19 in Indonesia: Where Are We? Acta Medica Indonesiana, 52(3), 193.

Arman. (2019). Lembaga Farmasi Angkatan Laut Dipercaya Sebagai Industri Farmasi Dalam Mengembangkan OST-D. Retrieved from https://www.liputanindonesianews.com/det ail/28492/lembaga-farmasi-angkatan-lautdipercaya-sebagai-industri-farmasi-dalammengembangkan-ostd.html

Herdady, M. R., \& Muchtaridi, M. (2020). COVID-19: Alarm Bagi Sistem Rantai Pasok Industri Farmasi. Majalah Farmasetika. Retrieved from https://doi.org/10.24198/mfarmasetika.v5i4. 27076

Indramadhini, L., \& Sitompul, P. P. (2015). Pengaruh Kausalitas Ekspor, Impor, Dan Gdp Di Indonesia. Media Ekonomi, 23(1), 11. Retrieved from https://doi.org/10.25105/me.v23i1.3292

Junus, D. (2016). PENGEMBANGAN KAPASITAS DINAS KESEHATAN KABUPATEN GORONTALO. Jurnal Ad'ministrare, 3(1), 51-56. Retrieved from https://doi.org/10.26858/ja.v3i1.1927

Kaban, R., Siregar, R. S. M., Sumarlin, S., Yusrina, P., Yunita, R., \& Aritonang, R. P. (2018). Perancangan Web Responsive Untuk Sistem Informasi Obat-Obatan.
Jurnal Manajemen Bisnis (JMB), 30(2).

Kemenperin. (2020). Kemenperin Pertajam Taji Industri Farmasi dan Alat Kesehatan.

Lardo, S. (2020). Strategi Pembangunan Kesehatan Dan Ketahanan Nasional Dalam Perspektif Daya Juang Bangsa. Jurnal Pertahanan \& Bela Negara, 10(1), 61. Retrieved from https://doi.org/10.33172/jpbh.v10i1.824

Lee, Y. H., \& Kim, Y. (2016). Analyzing interaction in $\mathrm{R} \& \mathrm{D}$ networks using the Triple Helix method: Evidence from industrial $\mathrm{R} \& \mathrm{D}$ programs in Korean government. Technological Forecasting and Social Change, 110, 93-105. Retrieved from

https://doi.org/https://doi.org/10.1016/j.tech fore. 2015.10.017

Mahfut, M. (2020). Aplikasi filogenetik di dunia biologi kesehatan: melacak pandemi patogen. Teknosains: media informasi sains dan teknologi, 14(2). Retrieved from https://doi.org/10.24252/teknosains.v14i2.1 5406

Mawarti, R. S. (2017). Prospek Industri Farmasi Di Indonesia. Jurnal Inspirasi, 8(2), 69-72. Retrieved from https://doi.org/10.35880/inspirasi.v8i2.105

Moerti, W. (2021). Data Terkini Covid-19 di Indonesia Januari 2021. Retrieved from https://www.merdeka.com/peristiwa/dataterkini-covid-19-di-indonesia-januari2021.html

Ngurah Diksa, I. G. B. (2021). Peramalan Gelombang Covid 19 Menggunakan Hybrid Nonlinear Regression Logistic - Double Exponential Smoothing di Indonesia dan Prancis. Jambura Journal of Mathematics, 3(1), 37-51. Retrieved from https://doi.org/10.34312/jjom.v3i1.7771

Nugroho, A. W. (2017). Review: Konservasi Keanekaragaman Hayati Melalui Tanaman Obat Dalam Hutan Di Indonesia Dengan Teknologi Farmasi: Potensi Dan Tantangan. Jurnal Sains Dan Kesehatan, 1(7), 377383. Retrieved from https://doi.org/10.25026/jsk.v1i7.71

Puskes TNI. (2020). Penerimaan Vitarma Tablet produk Lafial untuk penanganan Covid-19. Retrieved from http://puskestni.mil.id/detail-berita.php?idberita $=42$ 
Raharni, R., Supardi, S., \& Sari, I. D. (2018). Kemandirian dan Ketersediaan Obat Era Jaminan Kesehatan Nasional (JKN): Kebijakan, Harga, dan Produksi Obat. Media Penelitian Dan Pengembangan Kesehatan, 28(4), 219-228. Retrieved from https://doi.org/10.22435/mpk.v28i4.269

Redaksi JSS. (2016). Pabrik Obat Murah. Retrieved from http://www.jurnalsocialsecurity.com/sosial/ kesehatan/pabrik-obat-murah.html

Redaksi WE. (2021). Tantangan dan Kebijakan Vaksin Merah Putih untuk Percepatan Penanganan Pandemi Covid-19. Retrieved from

https://www.wartaekonomi.co.id/read32425 6/tantangan-dan-kebijakan-vaksin-merahputih-untuk-percepatan-penangananpandemi-covid-19

Rizni, F. (2016). Aspek dan pelaksanaan national drug policy di indonesia. Defendonesia, 1(2), 49-52.

Sari, I. P., \& Sriwidodo, S. (2020). Perkembangan Teknologi Terkini dalam Mempercepat Produksi Vaksin COVID-19. Majalah Farmasetika. Retrieved from https://doi.org/10.24198/mfarmasetika.v5i5. 28082
Satgas Penanganan COVID-19. (2020). Analisis Data COVID-19 Indonesia Update Per 03 Januari 2021. Retrieved from https://covid19.go.id/

Seto, S., Nita, Y., \& Triana, L. (2015). Manajemen Farmasi 2: Edisi 4: Lingkup apotek, farmasi rumah sakit, industri farmasi, pedagang besar farmasi. Surabaya: Airlangga University Press.

Usman, N. (2018). Implementasi Kebijakan Pengembangan Industri Alat Kesehatan Dalam Negeri. Jurnal Kebijakan Kesehatan Indonesia: JKKI, 7(1), 42-48. Retrieved from https://doi.org/10.22146/jkki.17936

Zuhriyah, D. A. (2019). 2021, Impor Bahan Baku untuk Industri Farmasi Ditarget Turun $15 \%$. Retrieved from https://ekonomi.bisnis.com/read/20191014/ 12/1158799/2021-impor-bahan-bakuuntuk-industri-farmasi-ditarget-turun-15 